The Bangladesh Veterinarian (2014) 31(1): 20 - 26

\title{
Bacterial contamination of street-vended spicy puffed-rice sold at Bangladesh Agricultural University campus
}

\author{
A Khandoker, MA Islam, MM Rahman, AA Husna, S Das ${ }^{1}$ and MM Khatun* \\ Department of Microbiology and Hygiene, Faculty of Veterinary Science, Bangladesh \\ Agricultural University, Mymensingh-2202, Bangladesh
}

\begin{abstract}
This study was undertaken to investigate the bacterial contamination of spicy puffed rice (Jhalmuri) sold by the street vendors at Bangladesh Agricultural University (BAU) campus. Fifteen spicy puffed rice samples were collected from street vendors at the Botanical Garden, Library premises, Riverside, Krishi Bishhobiddaloy (KB) High School and Veterinary Teaching Hospital compound at BAU campus. Microbial quality was assessed by total viable count (TVC), total coliform count (TCC) and total staphylococcal count (TSC). Samples were inoculated into selective media Eosin Methylene Blue (EMB) agar, Salmonella Shigella (SS) agar, Thiosulphate Citrate Bile Salts Sucrose (TCBS) agar and Mannitol Salt (MS) agar. E. coli and Staphylococcus spp. were identified from the samples. The TVC in spicy puffed rice sample ranged from log $4.5 \mathrm{cfu} / \mathrm{g}$ to $\log 5.4 \mathrm{cfu} / \mathrm{g}$, TSC ranged from $\log 4.4 \mathrm{cfu} / \mathrm{g}$ to $\log 5.2 \mathrm{cfu} / \mathrm{g}$ and TCC ranged from $\log 1.4 \mathrm{cfu} / \mathrm{g}$ to $\log$ $4.3 \mathrm{cfu} / \mathrm{g}$. Antibiotic sensitivity test showed that the isolates were sensitive to ciprofloxacin and gentamicin. E. coli were resistant to ampicillin, chloramphenicol and cephalexin and Staphylococcus spp. were resistant to ampicillin, cephalexin and vancomycin. Spicy puffed rice sold by the street vendors at BAU campus harboured multidrug resistant food borne bacteria which may cause public health hazard. (Bangl. vet. 2014. Vol. 31, No. 1, 20 - 26)
\end{abstract}

\section{Introduction}

Spicy puffed rice is a popular street food sold by hawkers or vendors on the street and other public places such as University campus, school premises, and railway and bus stations. People of all ages and classes like rickshaw pullers, labourers, students, and children eat spicy puffed rice because of its availability and reasonable price (Rahman et al., 2014). Street vended foods are known to be contaminated with pathogens, which might pose a public health hazard (Das et al., 2010; Sina et al., 2011; Madueke et al., 2014). Bacteria belonging to the genus Bacillus, Staphyloccus, Clostridium, Vibrio, Campylobacter, Listeria, Salmonella are reported from street vended food (Rahman et al., 2014). No study has been conducted in Bangladesh to assess the microbiological quality of spicy puffed rice sold by vendors. The objectives of this study were to identify bacteria from street-vended spicy puffed rice and to know the antibiotic sensitivity.

\footnotetext{
${ }^{1}$ Upazilla Livestock Officer, Delduar, Tangail, Bangladesh

*Corresponding author:- E-mail: minaramicro2003@yahoo.com
} 


\section{Materials and Methods}

\section{Collection of samples}

Fifteen spicy puffed rice (Jhalmuri) samples were collected from five vendors at the Bangladesh Agricultural University (BAU) campus such as: Botanical Garden, Library, Riverside, K. B. High School and Veterinary Teaching Hospital.

\section{Isolation of bacteria}

Homogenized samples were enriched into nutrient broth by overnight incubation at $37^{\circ} \mathrm{C}$. Overnight enriched culture was streaked duplicate onto Mannitol salt agar (MSA), Eosine Methylene Blue (EMB), Salmonella-Shigella (SS) agar, Thiosulphate Citrate Bile Salts Sucrose (TCBS) agar and incubated at $37^{\circ} \mathrm{C}$ for $24 \mathrm{hrs}$.

\section{Identification of bacteria}

Bacteria were identified by morphology of colonies (size, margin, elevation and colour), Gram's stain, sugar fermentation reaction, catalase, coagulase, Methyle Red (M-R), Voges Proskauer (V-P), and indole tests (Cheesbrough, 1985). Genus specific PCR assays were performed to identify Staphylococcus spp. and E. coli using previously published primers (Stuhlmeier \& Stuhlmeier, 2003; Huws et al., 2007).

\section{Antibiotic sensitivity}

Antibiotic sensitivity was tested using 0.5 McFarland turbidity standard inoculum and freshly prepared, dried Mueller Hinton agar (Oxoid, UK) against six common antibiotics: ampicillin, vancomycin, gentamicin, cephalexin, chloramphenicol and ciprofloxacin. Two isolates of E. coli and Staphylococcus spp. were selected randomly for the test. Disc diffusion or Kirby-Bauer method (Bauer et al., 1966) was used. The results were expressed as resistant, intermediate or sensitive according to the guidelines of Clinical Laboratory and Standards Institute (CLSI, 2007).

\section{Results and Discussion}

Total viable count (TVC) of spicy puffed rice

The bacterial load was the highest in samples from Botanical Garden (log $5.4 \pm 1.1$ $\mathrm{cfu} / \mathrm{g})$, followed by those from Riverside $(\log 5.0 \pm 0.5 \mathrm{cfu} / \mathrm{g}), \mathrm{K}$. B. High School (log $4.9 \pm 0.5 \mathrm{cfu} / \mathrm{g})$, Library $(\log 4.8 \pm 0.2 \mathrm{cfu} / \mathrm{g})$, Veterinary Teaching Hospital (log $4.5 \pm$ $0.2 \mathrm{cfu} / \mathrm{g}$ (Table 1$)$.

\section{Total staphylococcal count (TSC) of spicy puffed rice}

The staphylococcal load was highest in samples from Botanical Garden vendor (log $5.24 \pm 1.11 \mathrm{cfu} / \mathrm{g})$, followed by Riverside $(\log 4.70 \pm 0.44 \mathrm{cfu} / \mathrm{g})$, K. B. High School (log $4.70 \pm 0.46 \mathrm{cfu} / \mathrm{g})$, Library $(\log 4.50 \pm 0.20 \mathrm{cfu} / \mathrm{g})$, Veterinary Teaching Hospital (log $4.40 \pm 0.20 \mathrm{cfu} / \mathrm{g}$ ) (Table 2). 
Table 1. Total viable count of spicy puffed rice sold by street vendors at Bangladesh Agricultural University campus

\begin{tabular}{l|c}
\hline \multicolumn{1}{c|}{ Vendor place } & TVC (mean log cfu \pm SD $/ \mathrm{g})$ \\
\hline Botanical Garden & $5.4 \pm 1.1$ \\
Library premises & $4.8 \pm 0.2$ \\
Riverside & $5.0 \pm 0.5$ \\
K. B. High School & $4.9 \pm 0.5$ \\
Veterinary Teaching Hospital & $4.5 \pm 0.2$ \\
\hline
\end{tabular}

TVC: Total viable count, K. B.: Krishi Bishhobiddaloy

Table 2. Total staphylococcal count of spicy puffed rice sold by street vendors at Bangladesh Agricultural University campus

\begin{tabular}{l|c}
\hline \multicolumn{1}{c|}{ Vendor place } & TSC (mean log cfu \pm SD $/ \mathrm{g})$ \\
\hline Botanical Garden & $5.2 \pm 1.1$ \\
Library premises & $4.5 \pm 0.2$ \\
Riverside & $4.7 \pm 0.4$ \\
K. B. High School & $4.7 \pm 0.5$ \\
Veterinary Teaching Hospital & $4.4 \pm 0.2$ \\
\hline
\end{tabular}

TSC: Total staphylococcal count, K. B.: Krishi Bishhobiddaloy

Total coliform count (TCC) of spicy puffed rice

The coliform load was highest in samples from Library $(\log 4.3 \pm 0.0 \mathrm{cfu} / \mathrm{g}$ ), Botanical Garden $(\log 3.0 \pm 2.6 \mathrm{cfu} / \mathrm{g})$, Riverside $(\log 2.8 \pm 2.4 \mathrm{cfu} / \mathrm{g})$, Veterinary Teaching Hospital $(\log 2.8 \pm 2.4 \mathrm{cfu} / \mathrm{g})$, K. B. High School $(\log 1.4 \pm 2.5 \mathrm{cfu} / \mathrm{g})($ Table 3).

Table 3. Total coliform count of spicy puffed rice sold by street vendors at Bangladesh Agricultural University campus

\begin{tabular}{l|c}
\hline \multicolumn{1}{c|}{ Vendor place } & TCC (mean log cfu \pm SD $/ \mathrm{g})$ \\
\hline Botanical Garden & $3.0 \pm 2.6$ \\
Library premises & $4.3 \pm 0.0$ \\
Riverside & $2.8 \pm 2.4$ \\
K. B. High School & $1.4 \pm 2.5$ \\
Veterinary Teaching Hospital & $2.8 \pm 2.4$ \\
\hline
\end{tabular}

TCC: Total coliform count, K. B.: Krishi Bishhobiddaloy

\section{Isolation of bacteria}

Two genera of bacteria, Staphylococcus spp. and E. coli, were isolated from spicy puffed rice samples. Bacterial genera recovered are in agreement with earlier studies 
(Kaneko et al., 1999; Mensah et al., 2002; Das et al., 2010; Furlaneto et al., 2010; Sina et al., 2011; Madueke et al., 2014).

\section{Cultural, morphological and staining characteristics}

The cultural characteristics of E. coli and Staphylococcus spp. were similar to the findings of other authors (Sharada et al., 1999; Thomas et al., 2005; Konuku et al., 2012).

\section{Biochemical characteristics}

E. coli fermented dextrose, lactose, sucrose, maltose and mannitol with the production of acid and gas. E. coli gave positive reaction to MR and indole test and negative reaction to catalase and V-P test. Staphylococcus spp. fermented all five basic sugars with the production of acid. Catalase, MR and V-P test were positive but indole and coagulase tests were negative. These results are similar to those of Thomas (1998); Konuku et al. (2012).

Molecular detection of Staphylococcus spp. by PCR

DNA extracted from Staphylococcus spp. was used in PCR assay. PCR primers targeting 16S rRNA of Staphylococcus spp. amplified $241 \mathrm{bp}$ fragments of DNA confirmed the identity of Staphylococcus spp. (Fig. 1).

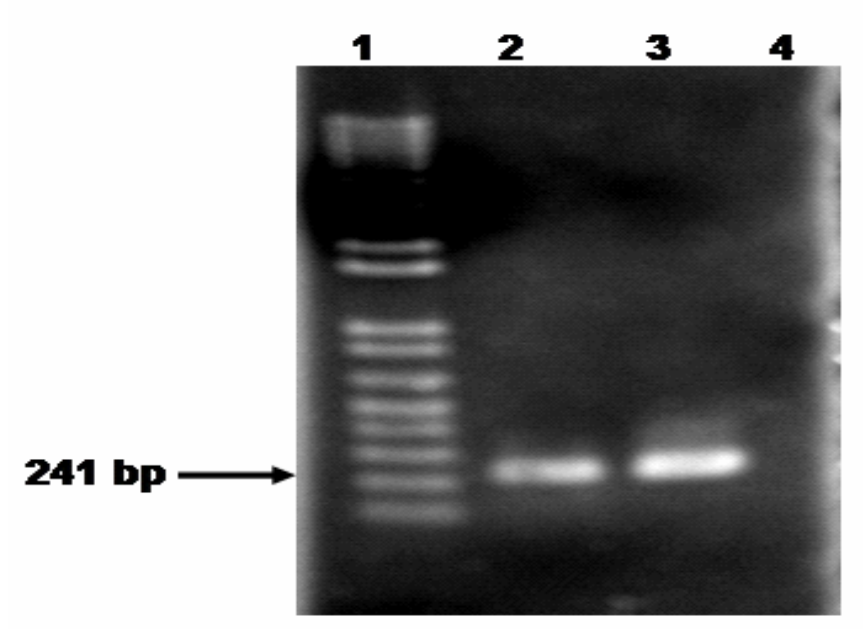

Fig. 1. Identification of Staphylococcus spp. by amplification of 16S rRNA gene by PCR. Lane 1: 100bp size DNA marker (Trackit, Invitrogen, USA); Lane 2: positive control DNA of Staphylococcus; Lane 3: DNA of bacteria isolated from spicy puffed rice; Lane 4: negative control without DNA

Molecular detection of E. coli

DNA extracted from five E. coli isolates were used in the polymerase chain reaction (PCR) assay. PCR primers targeting 16S rRNA of E. coli amplified $939 \mathrm{bp}$ fragments of DNA confirming the identity of E. coli (Fig. 2). 


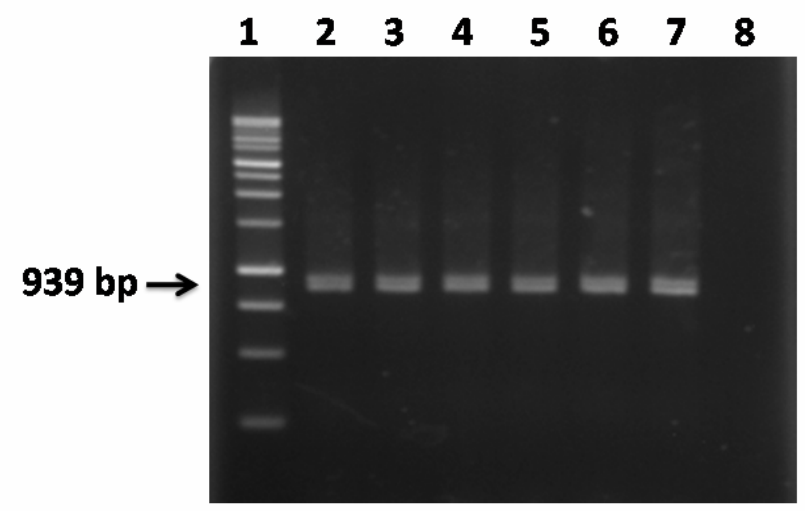

Fig. 2. Results of PCR for amplification of $16 \mathrm{~S}$ rRNA of E. coli isolates of spicy puffed rice. Lane 1: 1 kb size DNA marker (Promega, USA); Lane 2: Positive control; Lane 3: DNA from Botanical Garden; Lane 4: DNA from Riverside; Lane 5: DNA from K.B. High School; Lane 6: DNA from Library; Lane 7: DNA from Veterinary Teaching Hospital; Lane 8: Negative control without DNA.

\section{Antibiotic sensitivity test}

Staphylococcus spp. were resistant to ampicillin, vancomycin, cephalexin and sensitive to ciprofloxacin, chloramphenicol and gentamicin (Table 4). E. coli isolates were resistant to ampicillin, chloramphenicol, cephalexin and sensitive to ciprofloxacin and gentamicin (Table 5). The results are identical to those reported by $\mathrm{Lin}$ and Modarressi (2011); Singh et al. (2011); Tagoe et al. (2011).

Table 4. Antibiotic sensitivity of Staphylococcus spp.

\begin{tabular}{l|c|c}
\hline \multicolumn{1}{c}{ Name of antibiotics } & Diameter of zone of inhibition $(\mathrm{mm})$ & Interpretation \\
\hline Ampicillin & 9 & $\mathrm{R}$ \\
Chloramphenicol & 17 & $\mathrm{I}$ \\
Ciprofloxacin & 23 & $\mathrm{~S}$ \\
Gentamicin & 17 & $\mathrm{~S}$ \\
Cephalexin & 10 & $\mathrm{R}$ \\
Vancomycin & 10 & $\mathrm{R}$ \\
\hline
\end{tabular}

$\mathrm{R}=$ Resistant $\mathrm{S}$ = Sensitive, $\mathrm{I}=$ Intermediate

Table 5. Antibiotic sensitivity of E. coli

\begin{tabular}{l|c|c}
\hline \multicolumn{1}{c}{ Name of antibiotics } & Diameter of zone of inhibition $(\mathrm{mm})$ & Interpretation \\
\hline Ampicillin & 5 & $\mathrm{R}$ \\
Chloramphenicol & 10 & $\mathrm{R}$ \\
Ciprofloxacin & 21 & $\mathrm{~S}$ \\
Gentamicin & 21 & $\mathrm{~S}$ \\
Cephalexin & 7 & $\mathrm{R}$ \\
\hline
\end{tabular}

$\mathrm{R}=$ Resistant $\mathrm{S}=$ Sensitive 


\section{Conclusions}

The occurrence of bacteria resistant to many antibiotics in spicy puffed rice is of public health significance.

\section{References}

Bauer AW, Kirby WMM, Shrris JC, Truck M 1966: Antibiotic susceptibility testing by a standardized single disc method. American Journal of Clinical Pathology 45 493-496.

Cheesbrough M 1985: Medical laboratory manual for tropical countries. $1^{\text {st }}$ edn. Microbiology. English Language Book Society, London. pp: 400-480.

Clinical and Laboratory Standards Institute (CLSI, formerly NCCLS) 2007: Performance standards for antimicrobial susceptibility testing. 17th Informational Supplement document M100-S17: 1. Wayne, Pennsylvania. pp: 32-50.

Das A, Nagananda GS, Bhattacharya S, Bhardwaj S 2010: Microbiological quality of streetvended Indian chaats sold in Bangalore. Journal of Biological Sciences 10 255-260.

Furlaneto L, Oliveira MT, Oliveira AF 2010: Hygienic-sanitary condition, microbiological quality and antimicrobial susceptibility of isolated strains from sandwiches sold in street markets. Revista do Instituto Adolfo Lutz. 69 489-496.

Huws SA, Edwards JE, Kim EJ, Scollan ND 2007: Specificity and sensitivity of eubacterial primers utilized for molecular profiling of bacteria within complex microbial ecosystems. Journal of Microbiological Methods 70 565-569.

Kaneko K, Hayashidani H, Ohtomo Y, Kosuge J, Kato M, Takahashi K, Shiraki Y, Ogawa M 1999: Bacterial contamination of ready-to-eat foods and fresh products in retail shops and food factories. Journal of Food Protection 62 644-649.

Konuku S, Rajan MM, Muruhan S 2012: Morphological and biochemical characteristics and antibiotic resistance pattern of Staphylococcus aureus isolated from grapes. International Journal of Nutrition, Pharmacology, Neurological Diseases 2 70-73.

Lin KT, Modarressi S 2011: Antimicrobial resistant genes associated with Salmonella from retail meats and street foods. Food Research International $\mathbf{4 4}$ 2641-2646.

Madueke SN, Awe S, Jonah AI 2014: Microbiological analysis of street foods along LokojaAbuja Express Way, Lokoja. American Journal of Research Communication 2 196-211.

Mensah P, Manu D Y, Darko K O, Ablordey A 2002: Street foods in Accra, Ghana: how safe are they? Bulletin of the World Health Organization 80 546-554.

Rahman MM, Rahman MH, Ansary NP 2014: Safety Issues of Street Foods in Bangladesh. Time Journals of Biological Sciences and Technology 2 21-32.

Sharada R, Krishnappa G, Raghavan R, Sreevinas G, Upandra HA 1999: Isolation and serotyping of Escherichia coli from different pathological conditions in poultry. Indian Journal of Poultry Science 34 366-369. 
Sina H, Baba MF, Kayode AP, Noumavo PA, Sezan A, Hounhouigan JD, Kotchoni SO, Prevost G, Baba ML 2011: Characterization of Staphylococcus aureus isolated from street foods: toxin profile and prevalence of antibiotic resistance. Journal of Applied Biosciences 46 3133-3143.

Singh V, Chandel R, Chauhan P K, Bala I, Thakur K 2011: Prevalence and antibiogram pattern of bacteria isolated from food product (Burger) of street food vendors of Paonta Sahib. International Journal of Institutional Pharmacy and Life Sciences 86-90.

Stuhlmeier R, Stuhlmeier KM 2003: Fast, simultaneous and sensitive detection of Staphylococci. Ludwig Boltzmann Institute for Rheumatology and Balneology 56 782-785.

Tagoe DNA, Nyarko H, Arthur SA, Birikorang E 2011: A Study of antibiotic susceptibility pattern of bacterial isolates in sachet drinking water sold in the cape coast metropolis of Ghana. Research Journal of Microbiology 6 153-158.

Thomas AR, Bruce AD, Stacy A, Genagon NM, Warholic UM, Patrick D, Pawlicki JM, Beannan RO, Burce AH, Paul RK 2005: Escherichia coli virulence factor hemolysin induces neutrophil apoptosis and necrosis/lysis in vitro and necrosis/ lysis and lung injury in a rat pneumonia model. American Journal of Physiology-Lung cellular and Molecular Physiology 289 207-261.

Thomas CGA 1998: Gram-negative Bacilli. In: Medical Microbiology. 6th edn. Bailliere Tindall, Oxford, UK pp. 273-274. 